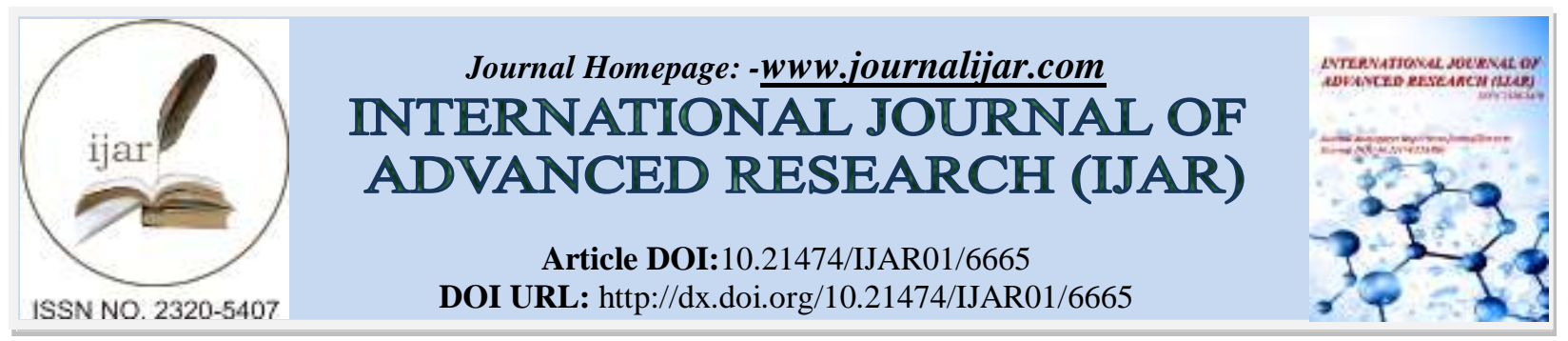

RESEARCH ARTICLE

\title{
APPLICATION OF MALDI- TOF MS TECHNOLOGY TO THE IDENTIFICATION AND CHARACTERIZATION OF PATHOGENS IN DAIRY INDUSTRY.
}

Linda Boultifat*, assia guendouze and mohamed abdelhafid hamidechi.

Laboratory of cellular and molecular biology Microbiology Department, Natural Sciences and Life Faculty, Constantine 1 University, Ain El Bey Road - 25000 Constantine - Algeria.

\section{Manuscript Info}

Manuscript History

Received: 04 January 2018

Final Accepted: 06 February 2018

Published: March 2018

Keywords:-

MALDI-TOF MS, pathogens identification, pasteurized milk, dairy industry.

\begin{abstract}
The prerequisite of any microbial identification technique, especially in food industry, is its accuracy. Furthermore, it should be easy to perform, fast and cost-effective to ensure safe products and identify their microbial contamination. In this study, we tested Matrix-Assisted Laser Desorption/Ionization Time-Of-Flight Mass Spectrometry (MALDI-TOF MS) as an efficient tool allowing identification of bacterial isolates with high confidence and speed. Five bacterial species were isolated from pasteurized milk samples collected from different steps of their line production, in a local dairy company in Constantine, Algeria. The isolates were analyzed by MALDI-TOF MS method and results were compared with those provided by sequencing of the $16 \mathrm{~S}$ rDNA gene in order to confirm the identification. All bacterial isolates were successfully identified by MALDI-TOF MS method to the species level (scores $\geq 2$ ). In parallel, 16S rDNA gene sequencing analysis identified the five isolates to the species level ( $\geq 99 \%$ sequence similarity). The results of MALDI-TOF MS-based identification of the bacterial isolates studied showed a total concordance $(100 \%$ same species) for isolates designed $\mathrm{S} 1, \mathrm{~S} 2$ and $\mathrm{B} 2$ to those of the reference method (16S rDNA gene sequencing), except for two cases (isolate B1 and B3), were the identification by both proteomic and genomic methods coincided at the genus level. This study suggests that comparatively to $16 \mathrm{~S}$ rDNA gene sequencing which provides limited results; MALDI- TOF MS is a highly sensitive and rapid method that could be used to identify pathogens in dairy industry.
\end{abstract}

Copy Right, IJAR, 2018,. All rights reserved.

\section{Introduction:-}

The detection and enumeration of pathogens in food is an important component of any integrated program to ensure the safety of foods throughout the food supply chain (Dos Santos et al., 2010). Food companies use microbiological analysis to identify microbial contamination, monitor its state at all times and analyze its trends so as to detect emerging risks. Microbiological analysis is an essential tool for carrying out tests in accordance with the microbiological criteria established for each food type, as well as being essential for evaluating the actions of different management strategies based on the Hazard Analysis and Critical Control Points (HACCP) system (Stannard 1997; Jasson et al. 2010). These analysis, mainly based on the morphological, physiological and 
biochemical tests, either before enrichment (quantitative or enumerative methods) or after enrichment (qualitative methods, also known as presence/absence tests), allow the identification of most bacterial isolates with great accuracy, but they are costly and time-consuming. The methods based on genetic markers, are often quite cost intensive and difficult to implement in routine food analysis (Dos Santos et al., 2010). Matrix Assisted Laser Desorption/Ionization-Time of Flight Mass Spectrometry (MALDI-TOF MS) has recently emerged as a rapid and accurate identification method for bacterial species (Jadhav et al., 2015). Compared with DNA analysis based technologies, MALDI-TOF MS requires smaller amounts of biological material and involves simpler sample preparation protocols with no initial assessment, such as Gram staining (Fenselau and Demirev, 2001; Mellmann et al., 2009; Ilina et al., 2010). In addition, this technique requires little MS expertise, the use of simple instruments, and relatively fast operator training (Dos Santos et al., 2010).

The MALDI-TOF MS technology has been used extensively in clinical diagnostics, however, its applicability to detection of foodborne pathogenesis comparatively is less explored (Jadhav et al., 2014; Pavlovic et al., 2013). In this context, our study aimed to evaluate the performance of MALD-TOF MS based identification of pathogens in dairy industry.

\section{Material and Methods:- Samples collection:-}

A total of three pasteurized milk samples were collected from different steps of their production process: before pasteurization, after pasteurization and ready to use product, in a dairy plant located in Constantine east of Algeria. The samples were collected aseptically in sterile containers, immediately kept in an ice box and transported to the laboratory. Samples were divided and used in triplicate for microbiology experiences.

\section{Microbiological analysis:-}

According to the standard method of the Official Journal of the Democratic and Popular Republic of Algeria, $\mathrm{N}^{\circ} 70$ of $07^{\text {th }}$ November 2004, the samples (described above) were investigated microbiologically for the total flora mesophilic aerobe, total and feacal coliform, the presence of Staphylococcus aureus and Salmonella sp in order to appreciate their hygienic quality. The conditions and selective media used in this study are summarized in Table 1.

Only Plate Count Agar (PCA) and Baird Parker Agar (BPA) plates, used respectively for the count of the total flora mesophilic aerobe and the search of Staphylococcus aureus, incubated under conditions indicated in table 1 were positive (giving visible growth). Single typical colony from each plate (PCA and BPA) was selected for this study. The selection of mesophilic colonies (growing on PCA) was based on their characteristics shape and color from countable plates (10 to 300). Colonies with typical Staphylococcuc morphology on BPA medium (black, convex and with or without a light halo) were counted. Afterwards, the selected colonies were sub cultured to purity on the same medium plates and then subjected to molecular identification to species level by both proteomic and genomic methods.

\section{MALDI-TOF Mass Spectrometry Analysis:-}

The identification of the isolates by MALDI-TOF mass spectrometry protein analysis was carried-out as described by Seng et al., 2009. It was performed on a Microflex LT instrument (Bruker Daltonics GmbH, Leipzig, Germany) with FlexControl (version 3.0) software (Bruker Daltonics) for the automatic acquisition of mass spectra in the linear positive mode within a range of 2 to $20 \mathrm{kDa}$, according to the instructions of the manufacturer. Analysis of the raw spectral data was performed by the MALDI BioTyper automation (version 2.0) software (Bruker Daltonics); it makes use of a large database containing reference spectra. The score value is defined by three components, the matches of the unknown spectrum against the main spectrum, the matches of the main spectrum peaks against the unknown spectrum, and the correlation of intensities of the matched peaks. This leads to a first score, from 0 (no match) to 1,000 (perfect identity), which is converted into a log score from 0 to 3 . When the score is greater than 2.0 is considered to indicate good species-level identification and scores above 2.3 correspond to excellent species-level identification. Values between 1.7 and 2.0 correspond to reliable genus-level identification and values below 1.7 indicate no identification (no significant similarity) (Cherkaoui et al., 2010). Sample preparation was performed according to the instructions of Bruker Daltonics. The bacterial isolates were grown on Columbia agar with $5 \%$ sheep blood (COSBA) and incubated for 24 hours at $37{ }^{\circ} \mathrm{C}$. Colony was directly deposited on an MSP 96 target plate (Bruker Daltonics). The preparation was overlaid with $1 \mu$ l of HCCA matrix solution, which is a (saturated solution of $\alpha$-cyano-4-hydroxycinnamic acid in 50\% acetonitrile- $2.5 \%$ trifluoroaceticacid). The colony was then air dried at room temperature to allow cocrystallization with the experimental sample. Each isolate was measured two times from three independent agar plates. At least two independent replicates out of three had to be concordant to be 
taken as valid for species or genus identification. The spectra acquired by the mass spectrometer were then compared by using the BioTyper software.

\section{Conventional PCR amplification and sequencing of the 16S rDNA gene:- DNA extraction:-}

The DNA extraction was carried out with the DNA tissue kit (QIAGEN, Hilden, Germany) using EZ1 instrument (QIAGEN). Samples were prepared according to the appropriate procedure, in the EZ1 DNA Tissue Handbook, respecting the amount of starting material $(200 \mu \mathrm{l})$. Colonies from each isolate were mixed with $180 \mu \mathrm{l}$ of extraction buffer and $20 \mu \mathrm{l}$ of proteinase $\mathrm{K}$ then incubated at $56^{\circ} \mathrm{C}$ overnight. The DNA can be analyzed immediately after the extraction or stored at $-20^{\circ} \mathrm{C}$ until analyzing.

\section{PCR amplification:-}

The 16S rDNA gene, for all isolates, was amplified with the universal primers 16S_fD1 and 16S_rP2 (Weisburg et al., 1991). PCR reaction was carried out in a final volume of $50 \mu$ l. Reaction mixtures contained $1 \times$ PCR buffer with $5 \mu$ template, $50 \mathrm{mM} \mathrm{KCl}, 1.5 \mathrm{mM} \mathrm{MgCl}$, desoxynucleoside triphosphate solution $(200 \mu \mathrm{M}$ each dATP, dCTP, dGTP and dTTP), $0.2 \mu \mathrm{M}$ each oligonucleotide primers and 0.5 units of Taq DNA polymerase. The thermal cycle consisted of an initial 10 min denaturation at $95^{\circ} \mathrm{C}$ followed by 39 cycles of 1 min denaturation at $95^{\circ} \mathrm{C}$, primer hybridization at $52^{\circ} \mathrm{C}$ for $30 \mathrm{~s}$ and a final 5 min elongation step at $72^{\circ} \mathrm{C}$. PCR reactions products were examined by electrophoresing and purified with the QIAquick spin PCR purification kit (Qiagen).

\section{Sequencing:-}

Sequencing was performed in ABI3700 automated capillary sequencer (Applied Biosystems, Foster City, California, United States) after a purification step of the PCR products, on the Sephadexplaq 5\%, with the use of a BigDye ${ }^{\circledR}$ Terminator v1.1 Cycle Sequencing Ready Reaction Kit (Applied Biosystems, Courtabeuf, France), the Bvd1, 5X Sequencing Buffer and the primers 357F, 357R, 536F, 536R, 800F, 800R, 1050F, 1050R (Table 2). The partial nucleotide sequences were combined into a single consensus sequence with ChromoasPro Software1.34 (Copyright (c) 2003-2006 by Technelysium Pty Ltd). The final obtained sequences were then compared with the GenBank database using BLAST software.

\section{Results:-}

All five bacterial species, isolated from pasteurized milk samples, gave spectra sufficient for species identification Figure. 1. As illustrated in Fig. 1 the MALDI-TOF MS profiles clearly differ in terms of number and intensity of mass signals. The obtained MALDI-TOF MS profiles were then compared to the reference spectra of the BioTyper database and their similarity was expressed by a BioTyper Log score. As shown in table 3, all isolates were identified to the species level (scores $\geq 2$ ).

In parallel with MALDI-TOF MS identification, all bacterial isolates were analyzed by $16 \mathrm{~S}$ rDNA gene sequencing, used as the reference method. By sequence comparison analysis, the five isolates were also identified to the species level ( $\geq 99 \%$ sequence similarity). The results of MALDI-TOF MS-based identification of the bacterial isolates studied showed a total concordance (100\% same species) for isolate designed S1, S2 and B2 to those of the reference method; except for two cases (isolate B1 and B3), were the identification by both proteomic and genomic methods coincided at the genus level. B1 and B3 were identified as Bacillus anthracis / Bacillus. cereus and Bacillus. Paralicheniformis / Bacillus. licheniformis respectively by $16 \mathrm{~S}$ rDNA sequencing and as $B$. cereus and B.licheniformis respectively by MALDI-TOF MS (Table 3).

\section{Discussion:-}

Bacteria play an important role in the food industry. They are used as starter cultures for cheese, yogurt or other fermented foods but they are also responsible for food-spoilage and food-poisoning. The identification and differentiation of food-related bacteria is indispensable for quality assurance and it is the basis for ensuring that safe (Wenning et al., 2014). Current microbiological techniques applied to foodborne pathogens detection are still based on usual approaches which are laborious and time consuming. On average, routine milk microbiological procedures take from 5 to 8 days to be completed and require the use of various biochemical tests and the evaluation of experts (Dos Santos et al ., 2010). 
Recently, bacterial identification at the molecular level has been investigated using matrix-assisted laser desorption/ionization time-of-flight mass spectrometry (MALDI-TOF MS) (Fenselau and Demirev, 2001). Many microorganisms have been identified by MALDI-TOF MS via characteristic "chemical signatures" in a highthroughput fashion using straightforward extraction and sample work-up protocols. After initial bacterial growth that requires 1 day on average, and using crude bacterial extracts or lysate supernatants of whole cells, bacterial determination has been performed by MALDI-TOF MS in a few minutes (Holland et al., 1999; Dos Santos et al., 2010).

In this context, the main objective of this study was to evaluate MALDI- TOF fingerprinting in the identification of pasteurized milk associated pathogens taking in account specific requirement of milk microbiological identification protocols.

In total, five different species isolated from pasteurized milk samples, belonging to Bacillus and Staphylococcus genus were identified. The detection of contamination by species of Bacillus genus can probably be explained by their ubiquitous character and their large distribution in the environment as it has reported by Bartoszewicza et al., 2008, which facilitates their contamination in a variety of foods at different stages of the food chain (Oguntoyinbo, 2007). Contamination can be mediated through various substrates including soil, grain and dairy equipments (Bartoszewicza et al., 2008). Many studies have reported that Bacillus cereus spp are common contaminants in a wide variety of food, including milk and other dairy products (Becker et al., 1994; Reyes et al., 2007; Bartoszewicza et al., 2008). Remarkably, these species are able to survive pasteurization and produce endospores in raw and thermally processed foods (Durak et al., 2006).

In particular, contamination of milk by members of the Bacillus cereus group is of significance, not only because of their spoilage capability, but also because of their potential to cause human diseases (Andersen Borge et al., 2001; Jans 'tova' et al., 2006). Indeed, B. cereus has been recognized to be a causative agent in food poisoning for more than 40 years and has been linked to foodborne emetic and diarrhoeal syndromes (Ghelardi et al., 2002). $B$. licheniformis has been associated with a variety of clinical syndromes and food poisoning incidents in humans, bovine toxaemia and abortions (Salkinoja- Salonen et al., 1999), and food spoilage incidents such as ropy bread (Sorokulova et al., 2003). B. subtilis is not typically considered a human pathogen but may occasionally contaminate food and cause food poisoning (Fernandez et al., 2013).

The sampling along different steps of the pasteurized milk production chain, allowed also a detection of staphylococci contamination. Both genetic and proteomic techniques, used in this study, have successfully identified two species: Staphylococcus cohnii and Staphylococcus saprophyticus. The presence of these species was probably due to contaminated environment and unhygienic manufacturing practices along the production chain. The same results showing the presence of these species in milk and other dairy products has been reported by many authors (De Luca et al., 1997; Delbe`s and Montel., 2005; Enquebaher Tarekgne et al., 2015).

In the present study, two isolates designed (B1 and B3) were identified as B. cereus and B. licheniformis by MALDI- TOF. However, $16 \mathrm{~S}$ rDNA gene sequencing identified the isolate (B1) to be B. anthracis with $100 \%$ of similarity with NCBI code (CP023001.1) and B. cereus with $100 \%$ of similarity with the accession number (CP023179.1). This isolate identified as B. anthracis /B. cereus exhibited high similarity to both B.cereus and B.anthracis and were unable to be differentiated by this analysis. As it has demonstrated in the study by Helgason et al., (2000), B. anthracis is genetically very closely related to some B. cereus and B. thuringiensis strains. The same applies to isolate (B3), results from BLAST analyses fail to discriminate clearly between $B$. licheniformis and $B$. paralicheniformis because of the high homology of their sequences.

It is to highlight that these isolates (B1 and B3) were identified as B. cereus and B. licheniformis respectively on the basis of morphological characteristics presented by their colonies on Columbia Sheep Blood Agar medium, Gram staining and by the study of some of their biochemical characteristics (unpublished work).

Our results confirm previous studies reporting difficulties in the identification of certain foodborne Bacillus spp; due to similarities in their 16s rDNA sequences (Fernández-No et al., 2013). Interestingly MALDI-TOF MS identified theses isolates with a high score (2,18 and 2,17) respectively for B1 and B3 (Tabale 3) showing its ability to differentiate between species in this group. In addition, from the data shown in Fig 1, it is also clear that MALDITOF MS provides characteristic protein profiles that allow for identification of different species from the same 
bacterial genus. These results are comparable to those reported in the studies realized by Dos santos et al., ( 2010) and Fernandez et al., (2013). The finding in this study confirm the accuracy of the MALDI-TOF MS fingerprinting approach in identifying Bacillus species isolated from pasteurized milk.

The 16s rDNA gene sequencing was the reference standard for the identification of bacterial species used in the present study. This genomic method is regarded as the most widely accepted gene for bacterial identification (Song et al., 2003). However, as for any identification method, limitations for 16S rDNA gene sequencing exist (Janda and Abbott, 2007). Compared to MALDI TOF MS method, it was the least successful for identification, limited by the high homology of the species sequences.

\section{Conclusion:-}

In conclusion, our study showed that MALDI-TOF MS can be used for accurate and rapid identification of pasteurized milk related pathogens with high sensitivity and specificity and is therefore a potential alternative to the traditional phenotypic and genotypic methods that are currently used. This technique, once integrated with the implementation of preventive systems such as the HACCP will substantially improve food safety.

Table 1:- Selective media and conditions of incubation used for the investigated flora according to the Official Journal of Democratic and Republic Of Algeria.

\begin{tabular}{|c|c|c|c|c|}
\hline Investigated flora & Selective medium & $\begin{array}{c}\text { Incubation } \\
\text { temperature }\left({ }^{\circ} \mathrm{C}\right)\end{array}$ & Incubation time & Reference \\
\hline $\begin{array}{c}\text { Total Flora Mesophilic } \\
\text { Aerobe(TFMA) }\end{array}$ & $\begin{array}{l}\text { Plate Count Agar } \\
\text { (PCA) }\end{array}$ & $30^{\circ} \mathrm{C}$ & 72 hours & $\begin{array}{l}\text { OJDROA* } \\
\text { N}^{\circ} 702004 .\end{array}$ \\
\hline Total coliform & $\begin{array}{l}\text { Desoxycholate- } \\
\text { Citrate- Lactose- } \\
\text { Agar (DCLA) }\end{array}$ & $30^{\circ} \mathrm{C}$ & 24 hours & $\begin{array}{l}\text { OJDROA* } \\
\text { No70 /2004 }^{\circ}\end{array}$ \\
\hline Feacal coliform & $\begin{array}{l}\text { Desoxycholate- } \\
\text { Citrate- Lactose- } \\
\text { Agar (DCLA) }\end{array}$ & $44^{\circ} \mathrm{C}$ & 24 hours & $\begin{array}{l}\text { OJDROA* } \\
\mathrm{N}^{\circ} 70 / 2004\end{array}$ \\
\hline Staphylococcus aureus. & $\begin{array}{l}\text { Baird Parker Agar } \\
\text { (BPA) }\end{array}$ & $37^{\circ} \mathrm{C}$ & 24 hours & $\begin{array}{l}\text { OJDROA* } \\
\mathrm{N}^{\circ} 70 / 2004\end{array}$ \\
\hline Salmonella sp. & $\begin{array}{l}\text { Enrichement on: } \\
\text {-sélénite-cystine } \\
\quad \text { Broth } \\
\text {-Muller Kauffmann } \\
\text { supplemented with } \\
\text { tétrathionate and } \\
\text { Brilliant Green } \\
\text { Isolement on: } \\
\text { Hektoen Agar }\end{array}$ & $\begin{array}{c}37^{\circ} \mathrm{C} \pm 1 \\
43^{\circ} \mathrm{C} \pm 1 \\
37^{\circ} \mathrm{C}\end{array}$ & $\begin{array}{l}48 \text { hours } \\
48 \text { hours } \\
24 \text { hours }\end{array}$ & $\begin{array}{l}\text { OJDROA* } \\
\text { N}^{\circ} 70 / 2004\end{array}$ \\
\hline
\end{tabular}

(*)Official Journal of Democratic and Republic Of Algeria $\mathrm{N}^{\circ} 70$ of the $07^{\text {th }}$ December 2004.

Table 2:- Primers used in Conventional PCR amplification and sequencing of the 16S rDNA gene.

\begin{tabular}{|l|c|c|c|}
\hline & Primers & Sequence $\left(\mathbf{5}^{\prime}-\mathbf{3}^{\prime}\right)$ & $\mathbf{T}$ \\
\hline \multirow{3}{*}{ Amplification } & $\left.{ }^{\circ} \mathbf{C}\right)$ \\
\hline \multirow{5}{*}{ Sequencing } & fD1 & AGAGTTTGATCATGGCTCAG & 56 \\
\cline { 2 - 4 } & rP2 & ACGGCTACCTTGTTACGACTT & 62 \\
\cline { 2 - 4 } & $357 \mathrm{~F}$ & ACGGCTACCTTGTTACGACTT & 50 \\
\cline { 2 - 4 } & $357 \mathrm{R}$ & CTGCTGCCTCCCGTA & 58 \\
\cline { 2 - 4 } & $536 \mathrm{~F}$ & CTGCTGCCTCCCGTA & 58 \\
\cline { 2 - 4 } & $536 \mathrm{R}$ & GTATTACCGCGGCTGCTG & 48 \\
\cline { 2 - 4 } & $800 \mathrm{~F}$ & GTATTACCGCGGCTGCTG & 48 \\
\cline { 2 - 4 } & $800 \mathrm{R}$ & CTACCAGGGTATCTAAT & 48 \\
\hline
\end{tabular}

*: Tm values were determined using the formula: $\mathrm{Tm}=(2 \times \mathrm{AT}+4 \times \mathrm{GC})-4$. 
Table 3:- Comparison of 16S rDNA Sequencing and MALDI-TOF MS results for the 5 isolates.

\begin{tabular}{|c|c|c|c|c|c|}
\hline \multirow[b]{2}{*}{ isolate } & \multicolumn{2}{|c|}{ 16S rDNA gene sequencing } & \multicolumn{3}{|c|}{ MALDI-TOF MS } \\
\hline & Species ID* & $\begin{array}{l}\text { Level of } \\
\text { ID* }\end{array}$ & Species ID* & $\begin{array}{l}\text { Level of } \\
\text { ID* }\end{array}$ & Score \\
\hline B1 & Bacillus anthracis / B. cereus & Species & Bacillus cereus & Species & 2,181 \\
\hline B2 & Bacillus subtilis & Species & Bacillus subtilis & Species & 2,124 \\
\hline B3 & $\begin{array}{l}\text { Bacilus paralicheniformis / B. } \\
\text { licheniformis. }\end{array}$ & Species & Bacilus licheniformis & Species & 2,179 \\
\hline S1 & Staphylococcus cohnii & Species & Staphylococcus cohnii & Species & 2,213 \\
\hline $\mathrm{S} 2$ & Staphylococcus saprophyticus & Species & Staphylococcus & Species & 2,164 \\
\hline
\end{tabular}

ID*: Identification.
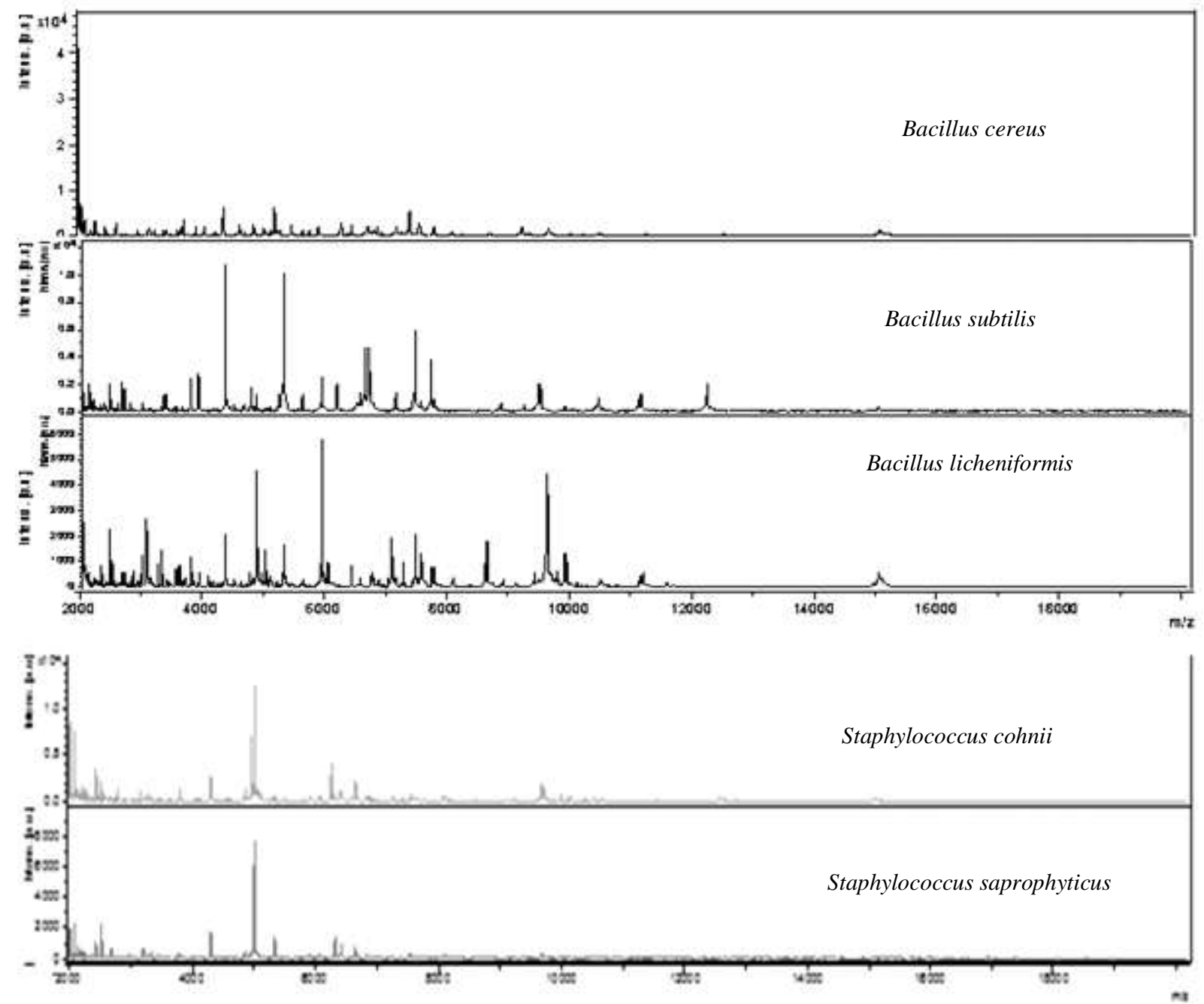

Figure 1:- The characteristic protein profiles obtained for the 5 bacterial isolates by Matrix assisted laser desorption/ionization-time-of-flight mass spectrometry.

\section{Acknowledgment:-}

We are grateful to Professor Didier RAOULT and Professor Jean Marc ROLAIN from Aix Marseille University, Rickettsies unit, Medicine Faculty, Marseille, France for their assistance in MALDI-TOF MS analyses. 


\section{References:-}

1. Andersen Borge, G.I., Skeie, M., Sorhaug, T., Langsrud, T., Granum,P.E. (2001): Growth and toxin profiles of Bacillus cereus isolated from different food sources. Int. J. Food Microbiol., 69: 237-246.

2. Bartoszewicza, M., Hansenb, BM., Swiecickaa, I. (2008): The members of the Bacillus cereus group are commonly present contaminants of fresh and heat-treated milk. Food Microbiology., 25: 588-596.

3. Becker, H., Schaller, W., von Wiese, W., Terplan, G. (1994): Bacillus cereus in infant foods and dried milk products. Int. J. Food Microbiol., $23: 1-15$.

4. Cherkaoui, A., Hibbs, J., Emonet, S., Tangomo, M., Girard, M., Francois, P. and Schrenzel, J. (2010): Comparison of two matrix-assisted laser desorption ionization time-offlight mass spectrometry methods with conventional phenotypic identification for routine identification of bacteria to the species level. J. Clin. Microbiol., 48: 1169-1175.

5. De Luca, G., Zanetti, F., Stampi, S. Short communication. (1997): Staphylococcus aureus in dairy products in the Bologna area. International Journal of Food Microbiology., 35: 267-270.

6. Delbe`s, C and Montel, M.C.(2005): Design and application of a Staphylococcus-specific single strand conformation polymorphism-PCR analysis to monitor Staphylococcus populations diversity and dynamics during production of raw milk cheese. Letters in Applied Microbiology., 41: 169-174.

7. Dos Santos, M.V., Barreiro, J. R., Ferreira, C. R., Sanvido, G. B., Kostrzewa, M., Maier, T., Wegemann, B., Böttcher, V., Eberlin, M. N.,. (2010): Identification of subclinical cow mastitis pathogens in milk by matrix-assisted laser desorption/ionization time-of-flight mass spectrometry. J. Dairy Sci., 93:5661-5667

8. Durak, M., Fromm, H., Huck, J., Zadoks, R., Boor, K. (2006): Development of molecular typing methods for Bacillus spp. and Paenibacillus spp. isolated from fluid milk products. Journal of Food Science., 71: M50M56.

9. Enquebaher Tarekgne, Siv Skeie1, Knut Rudi1, Taran Skjerdal and Judith A. Narvhus. (2015): Staphylococcus aureus and other Staphylococcus species in milk and milk products from Tigray region, Northern Ethiopia. African Journal of food Science., 9 (12): 567-576.

10. Fenselau, C. and Demirev P.A. (2001): Characterization of intact microorganisms by MALDI mass spectrometry. Mass Spectrom. Rev., 20:157-171.

11. Fernández-No, I.C., Böhme, K., Díaz-Bao, M., Cepeda, A., Barros-Velázquez, J., Calo-Mata, P. (2013): Characterisation and profiling of Bacillus subtilis, Bacillus cereus and Bacillus licheniformis by MALDI-TOF mass fingerprinting. Food Microbiology., 33: 235-242.

12. Ghelardi, E., Celandroni, F., Salvetti, S., Barsotti, C., Baggiani, A., Senesi, S. (2002): Identification and characterization of toxigenic Bacillus cereus isolates responsible for two food-poisoning outbreaks. FEMS Microbiology Letters., $208: 129-134$.

13. Helgason, E., Økstad, O.A., Caugant, D.A., Johansen, H.A., Fouet, A., Mock, M., Hegna, I and BritkolstØ, A. (2000): Bacillus anthracis, Bacillus cereus, and Bacillus thuringiensis. One Species on the Basis of Genetic Evidence. Applied and Environmental Microbiology., 66: 2627-2630.

14. Holland, R.D., Wilkes, J.G., Rafii, F., Sutherland, J.B., Persons, C.C., Voorhees, K.J and Lay, J.O. (1996): Rapid identification of intact whole bacteria based on spectral patterns using matrix assisted laser desorption/ionization with time-of-flight mass spectrometry. Rapid Commun. Mass Spectrom., 10:1227-1232.

15. Ilina, E. N., Borovskaya, A.D., Serebryakova, M.V., Chelysheva, V.V., Momynaliev, K.T., Maier, T., Kostrzewa, M and V. M. Govorun.( 2010): Application of matrix-assisted laser desorption/ionization time-offlight mass spectrometry for the study of Helicobacter pylori., Rapid Commun. Mass Spectrom. 24:328-334.

16. Jadhav, S., Sevior, D., Bhave, M., Palombo, E.A. (2014): Detection of Listeria monocytogenes from selective enrichment broth using MALDI-TOF mass spectrometry. Journal of Proteomics., 97: 100-106.

17. Jadhav, Snehal, Gulati, Vandana, Fox, Edward M., Karpe, Avinash, Beale, David J.,

18. Janda, J.M. and Abbott, S.L. (2007): 16S rRNA gene sequencing for bacterial identification in the diagnostic laboratory: pluses, perils, and pitfalls. J. Clin. Microbiol., 45:2761-2764.

19. Jans`tova, B., Dračkova, M., Vorlova', L. (2006): Effect of Bacillus cereus enzymes on the milk quality following ultra high temperature processing. Acta. Vet. Brno., 75: 601-609.

20. Jasson, V., Jacxsens, L., Luning, P., Rajkovic, A., Uyttendaele, M. (2010): Review. Alternative microbial methods: An overview and selection criteria. Food Microbiol., 27:710-730.

21. Kostrzewa, M and V. M. Govorun.( 2010): Application of matrix-assisted laser desorption/ionization timeof-flight mass spectrometry for the study of Helicobacter pylori., Rapid Commun. Mass Spectrom. 24:328-334.

22. Mellmann, A., Bimet, F., Bizet, C., Borovskaya, A.D., Drake,R. R., Eigner, U., Fahr, A.M., He, Y., Ilina, E.N., Kostrzewa, M., Maier, T., Mancinelli, L., Moussaoui, W., Prevost, G., Putignani, L., Seachord, C.L., Tang,Y.W and Harmsen, D. (2009): High interlaboratory reproducibility of matrix-assisted 
laser desorption ionization-time of flight mass spectrometry-based species identification of nonfermenting bacteria., J. Clin. Microbiol. 47:3732-3734.

23. Official Journal of Democratic and Republic Of Algeria $\mathbf{N}^{\circ} \mathbf{7 0 .}$ (2004) : Method of sample preparation for testing and dilutions for microbiological examination

24. Oguntoyinbo, F. (2007): Monitoring of marine Bacillus diversity among the bacteria community of sea water. African Journal of Biotechnology., 6: 163-166.

25. Pavlovic, M., Huber, I., Konrad, R and Busch, U. (2013): Application of MALDI-TOF MS for the identification of food borne bacteria. Open Microbiology Journal., 7: 135-141.

26. Reyesa,J.E., Bastı́asa,J.M., Gutie'rreza,M.R., Rodríguezb,M. (2007): Prevalence of Bacillus cereus in dried milk products used by Chilean School Feeding Program.Food. Microbiology., 24 :1-6.

27. Salkinoja-Salonen, M., Vuorio, R., Andersson, M., Kampfer, P., Honkanen-Buzalski, T. (1999): Toxigenic strains of Bacillus licheniformis related to food poisoning. Applied and Environmental Microbiology., 65: 46374645.

28. Seng, P., Drancourt, M., Gouriet, F., La, S.B., Fournier, P.E., Rolain, J.M and Raoult D. (2009): Ongoing revolution in bacteriology: routine identification of bacteria by matrix-assisted laser desorption ionization timeof-flight mass spectrometry. Clin. Infect. Dis., 49:543-551.

29. Sevior, Danielle, Bhave, Mrinal, Palombo, Enzo A. (2015): Rapid identification and source-tracking of Listeria monocytogenes using MALDI-TOF mass spectrometry. Int. J. Food Microbiol., 202: 1-9.

30. Song, Y., Liu, C., McTeague, M. and Finegold, S.M. (2003): 16S ribosomal DNA sequence-based analysis of clinically significant gram-positive anaerobic cocci. J. Clin. Microbiol., 41:1363-1369.

31. Sorokulova, I., Reva, O., Smirnov, V., Pinchuk, I., Lapa, S., Urdaci, M. (2003): Genetic diversity and involvement in bread spoilage of Bacillus strains isolated from flour and ropy bread. Letters in Applied Microbiology., 37: 169-173.

32. Stannard, C. (1997): Development and use of microbiological criteria for foods. Food. Sci. Technol. Today., 11:137-177.

33. Weisburg, W.G., Barns.S.M., Pelletier, D.A., Lane, D.J. (1991) : 16S Ribosomal DNA Amplification for Phylogenetic study. J Bacteriology., 173:697-703.

34. Wenning, M., Breitenwieser, F., Konrad, R., Huber, I., Busch, U., Scherer, S. (2014): Identification and differentiation of food-related bacteria: A comparison of FTIR spectroscopy and MALDI-TOF mass spectrometry. Journal of Microbiological Methods., (103): 44-52. 